\title{
Plant economy of the Trzciniec culture based on charred plant remains from Pielgrzymowice 9 site, in the context of archaeobotanical finds from southern Poland
}

\author{
MAGDA KAPCIA \\ W. Szafer Institute of Botany, Polish Academy of Sciences, Lubicz 46, 31-512 Kraków, Poland; \\ e-mail: magdakapcia@wp.pl \\ Received 4 October 2021; accepted for publication 20 December 2021
}

\begin{abstract}
In the paper, new carpological data from Pielgrzymowice site 9 are presented in the context of archaeobotanical finds from southern Poland. The results were obtained from detailed analyses of 45 samples from 38 archaeological features. Only charred plant remains were taken into account as they are considered contemporaneous with the Middle Bronze Age settlement. Among the cultivated plants, Panicum miliaceum, Triticum dicoccum, Triticum monococcum and Triticum sp. were documented. Among wild plants, several taxa were found, including Chenopodium t. album, Chenopodium sp., Melandrium / Silene, Polygonum lapathifolium and Fallopia convolvulus, among others. In archaeobotanical samples, Geranium sp., cf. Lamiaceae also appeared. In addition, plants typical of grasslands, forests and ruderal areas were noted, such as Coronilla varia, Rumex acetosella, Plantago media, Plantago lanceolata, Stellaria graminea and Hypericum perforatum. These results were compared with data coming from nine sites of the Trzciniec culture from Lesser Poland to track the Middle Bronze Age plant-based economy in southern Poland.
\end{abstract}

KEYWORDS: plant remains, Trzciniec culture, Bronze Age, Panicum

\section{INTRODUCTION}

A study of plant remains is an important element of archaeological works, thanks to which we can learn about the economy of former communities and try to reconstruct the natural environment of the past. Based on archaeobotanical research, we can identify plants that were cultivated and harvested by humans and characterize the vegetation surrounding former human settlements (Lityńska-Zając and Wasylikowa, 2005). The history of cultivated species and plants related to the economic activity of ancient populations on the territory of Poland can be traced back to the second half of the $6^{\text {th }}$ millennium $\mathrm{BC}$, when agriculture appeared with the arrival of the first farming communities (Kaczanowski and Kozłowski, 1998).
Several Neolithic archaeological sites provided valuable data showing various uses of cultivated and wild plants (Bieniek, 2007; LityńskaZając, 2007; Lityńska-Zając et al., 2017; Nowak et al., 2020). In contrast, Early and Middle Bronze Age archaeobotanical data are usually scarce, both in terms of the number of archaeological sites and the amount of preserved plant remains (Lityńska-Zając, 1994; Lityńska-Zając et al., 2014, 2015; Moskal-del Hoyo et al., 2015) with only a few exceptions (Słonowice site G - Lityńska-Zając and Makowicz-Poliszot, 2019; Lipnik site 5 - Bieniek, 2008; Kapcia and Mueller-Bieniek, 2019). In this context, the new results of archaeobotanical research from the Middle Bronze Age, presented in this 
paper, may constitute an important source supplementing the state of knowledge about the plants used during this period. Therefore, the aim of the research was an attempt to shed light on the plant-based economy of the Trzciniec culture population, based on archaeobotanical finds from the Pielgrzymowice site 9 located in Lesser Poland (Małopolska) (Fig. 1).

The Trzciniec culture emerged at the beginning of the 2nd millennium BC in Greater Poland (Wielkopolska), Mazovia (Mazowsze), Podlachia (Podlasie) and adjacent territories. The western Neolithic and eastern SubNeolithic traditions were influenced by the Early Bronze Age Unetice culture, leading to the formation of a new entity, the Trzciniec culture (Górski, 2017). The new cultural tradition was mentioned for the first time by Józef Kostrzewski in 1930 at the Polish Prehistorical Society meeting in Poznań (Machnik, 1998). The Trzciniec culture is characterized by findings of a similar set of vessels, at sites representing diverse palaeoeconomy and funeral traditions. In Lesser Poland, first sites associated with Trzciniec culture appeared in the 17th and 16th centuries BC. Initially, Trzciniec communities probably inhabited less fertile sandy soils, but after the Early Bronze Age groups of the Mierzanowicka culture started to disappear, Trzciniec settlers moved to more fertile loess soils (Górski, 2017). Based on preserved archaeobotanical and archaeozoological remains from other archaeological sites, it can be concluded that the economy of the population of the Trzciniec culture was based on animal husbandry and agriculture (Makarowicz, 1998, 2010; Górski et al., 2004; Mueller-Bieniek et al., 2015; Lityńska-Zając and MakowiczPoliszot, 2019). Prevailing regional environmental conditions (climate, distance from rivers, topography, vegetation) determined the dominant economy type. Unfortunately, many Trzciniec sites in Poland lack well-preserved animal bones or a rich set of plant remains, but crop farming is confirmed by the finds known as "harvesting tools" made of flint or bronze (Libera, 2001, 2014; Dąbrowski, 2004; Urban, 2008); although the presence of sickles can only

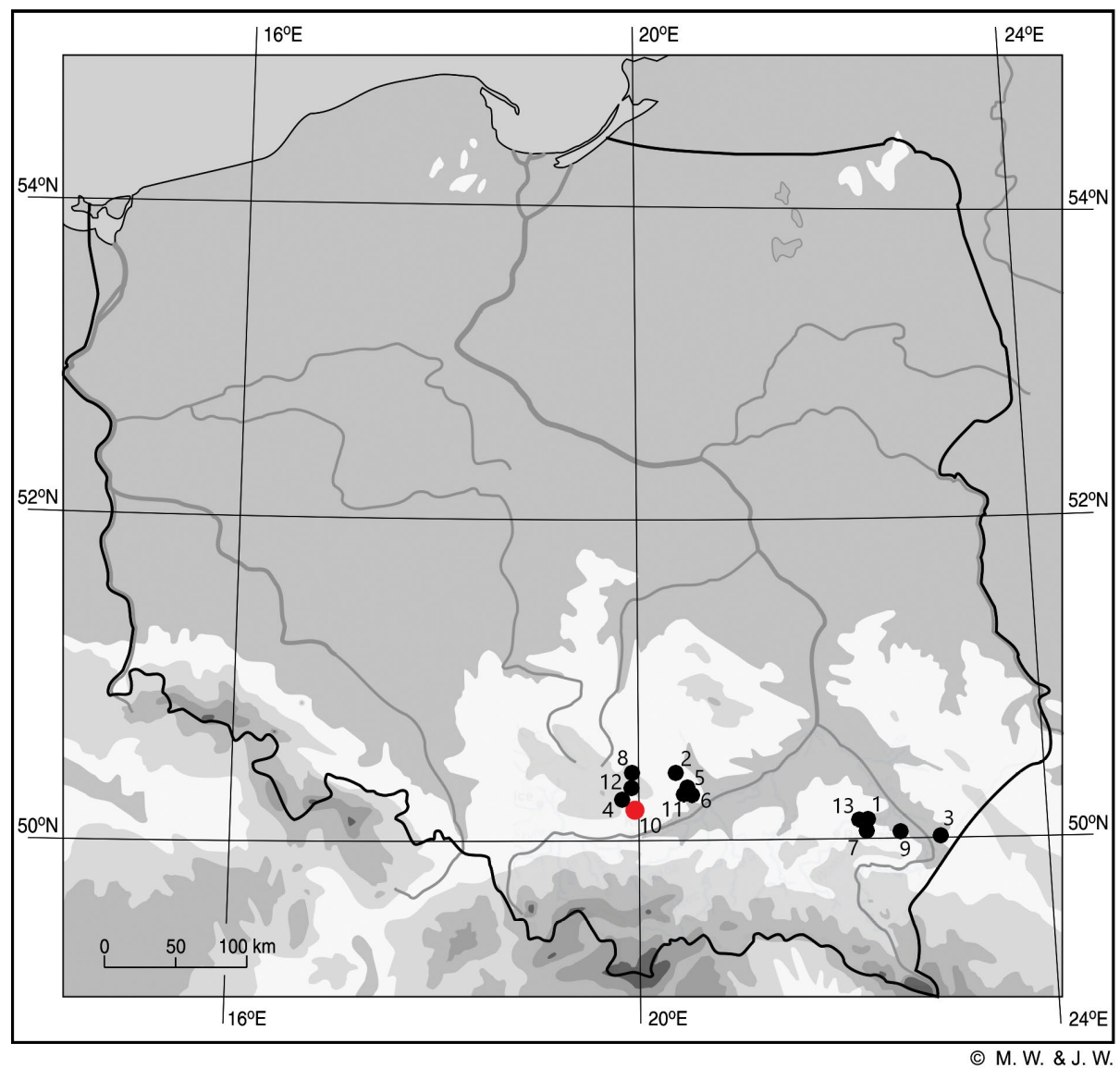

Fig. 1. Location of Trzciniec culture site. 1 - Białobrzegi 8, 2 - Bronocice 1, 3 - Chotyniec 36, 4 - Iwanowice-Babia Góra, 5 Jakuszowice, 6 - Kazimierza Mała 5, 7 - Lipnik 5, 8 - Miechów 3, 9 - Pawłosiów 2, 10 - Pielgrzymowice 9, 11 - Słonowice 4, Słonowice G, 12 - Smorków 17, 13 - Wola Mała 
indirectly indicate the cultivation of the land, as they could also be used to cut grass or twigs (Urban, 2008). However, in southern Poland, there are only a few archaeological sites that provided archaeobotanical plant remains from the Trzciniec culture. These include IwanowiceBabia Góra (Lityńska-Zając, 1994), Jakuszowice site 2 (Lityńska-Zając, 1999), Kazimierza Mała (Kruk et al., 2016), Słonowice site 4 and G (Calderoni et al., 1998-2000; LityńskaZając and Makowicz-Poliszot, 2019), Smroków site 17 (Lityńska-Zając, 2010), Miechów site 3 (Kapcia, unpublished), Lipnik site 5 (Bieniek, 2008; Kapcia and Mueller-Bieniek, 2019), and Białobrzegi site 8 (Kapcia, unpublished).

The Trzciniec settlement at Pielgrzymowice site 9 is located in a loess region of Lesser Poland, in the eastern part of the Michałowice district, on the border with the KocmyrzówLuborzyca district. It is situated on the border of the southwestern part of the Miechów Upland and the south-eastern part of the Kraków-Częstochowa Upland, $10 \mathrm{~km}$ north of the center of Kraków. The site is located in the valley of the Dłubnia River, which is the left tributary of the Wisła River. The archaeological works at Pielgrzymowice site 9 were part of the S7 expressway project. Site works were supervised by Anna Krzywda and Mirosław Kuś. The multicultural character of this site was confirmed by findings of features and artifacts associated with the Trzciniec culture, the Wyciąże-Złotniki group of the Lengyel-Polgár cultural complex, the Corded Ware culture, and the Lusatian culture (Krzywda and Kuś, oral communication).

\section{MATERIALS AND METHODS}

The archaeobotanical materials of the Trzciniec culture obtained from the Pielgrzymowice 9 site came from 45 samples gathered from 38 archaeological features (contexts that produced archaeobotanical samples were dated using artifacts, as no ${ }^{14} \mathrm{C}$ samples were taken) (Krzywda, Kuś, oral communication). However, the samples were taken without any advanced sampling strategy. Usually, one or two small volume (1-1.2 liter) samples were taken from a single feature. Samples were then floated through sieves with a mesh size of $1 \mathrm{~mm}$ and $0.5 \mathrm{~mm}$ and then delivered for the analysis to the W. Szafer Institute of Botany of the Polish Academy of Sciences (IB PAS). After drying, the material suitable for taxonomic identification was examined under a stereoscopic microscope and divided into seeds/fruits and charcoals. Plant remains were found in 27 samples from 22 features (nos. 14, 24, 123, 139, 146, 192, 202,
$241,252,281,392,495,496,559,646,651,669,678$, $681,785,787,907)$. Charcoal fragments were found in 40 samples, while 3 samples were empty.

Plant remains were classified based on morphological features visible under a stereoscopic microscope at $10 \times$ and $16 \times$ magnification. The seeds were identified using keys, atlases, and other publications (e.g. Kulpa, 1974; Rutkowski, 1998; Lityńska-Zając and Wasylikowa, 2005) and a reference collection of contemporary diasporas, as well as the collection of fossil floras of the National Biodiversity Collection of Recent and Fossil Organisms at the W. Szafer Institute of Botany, Polish Academy of Sciences (herbarium KRAM) in Cracow.

\section{RESULTS}

29 taxa were found in samples from Pielgrzymowice site 9, which were identified to family level (Poaceae, Brassicaceae, Chenopodiaceae, Fabaceae, Lamiaceae, Rosaceae and Rubiaceae), genus level (Triticum sp., Chenopodium sp., Poa sp., Geranium sp., cf. Valerianella and cf. Viola) and species level (Triticum dicoccum, Triticum monococcum, Panicum miliaceum, Chenopodium t. album, Polygonum lapathifolium, Coronilla varia, Fallopia convulvulus, Rumex acetosella, Plantago media, Plantago lanceolata and Hypericum perforatum). In some cases, based on morphological features of the preserved specimens, it was not possible to identify them to one genus (Pisum/Vicia and Melandrium/Silene). Due to poor preservation, several specimens could not be identified (indeterminate). Summarized quantitative data from Pielgrzymowice 9 are presented in Table 1 . This table includes also the uncharred material, although this assemblage is not taken into consideration for further interpretation of the data, due to its contemporary nature. Therefore, only charred remains are considered contemporary to the period when the archaeological features were formed, although we cannot exclude some post-deposit disturbances. Charcoal fragments were also found in Pielgrzymowice 9 samples (Moskal-del Hoyo, 2021), but they are out of the scope of this paper.

All determined plants have been assigned to four ecological groups: (1) cultivated crops, (2) weeds/ruderal plants, (3) meadow/pasture plants and (4) various (species probably grew in forest, water, wetland) and unspecified plants (Mueller-Bieniek and Woch, 2012). Plant material was divided by ecological groups following several monographs and articles on archaeobotanical finds (Lityńska-Zając, 1997, 
Table 1. Plant remains from Trzciniec culture Pielgrzymowice 9 site (gm. Michałowice, southern Poland): * - uncharred remains, gb - glume bases, c - caryopsis, grain, s - seed, $\mathrm{f}$ - fruit

\begin{tabular}{|c|c|c|c|c|c|c|c|c|c|c|c|c|c|c|c|c|c|c|c|c|c|c|c|c|c|}
\hline \multicolumn{2}{|l|}{ Feature number } & 5 & $\stackrel{H}{N}$ & $\begin{array}{l}\infty \\
6 \\
6\end{array}$ & ลे & S & O & 是 & 跑 & 竎 & - & $\stackrel{\infty}{\infty}$ & $\begin{array}{l}10 \\
\infty \\
1\end{array}$ & $\begin{array}{l}-1 \\
0\end{array}$ & s. & 0 & $\ddot{8}$ & 尺े & $\stackrel{\Re}{\stackrel{N}{-}}$ & $\begin{array}{l}* \\
0 \\
0\end{array}$ & H & $\stackrel{20}{9}$ & \& & สี & $\stackrel{9}{\rightarrow}$ \\
\hline \multicolumn{2}{|l|}{ Botanical number } & $\rightarrow$ & N & $\infty$ & + & 10 & $\infty$ & $\exists$ & $\stackrel{\sim}{\sim}$ & $\stackrel{10}{-1}$ & $\stackrel{0}{-1}$ & $\underset{\substack{\stackrel{N}{N} \\
\infty}}{\sim}$ & คิ & $\overrightarrow{\mathrm{N}}$ & $\underset{\substack{\text { I } \\
\text { f }}}{ }$ & เู & 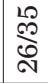 & - & 命 & $\infty$ & 尺ి & 아 & F & F & $\stackrel{H}{H}$ \\
\hline \multicolumn{26}{|c|}{$\begin{array}{l}\text { Plant name } \quad \text { kind of remains } \\
\end{array}$} \\
\hline \multicolumn{26}{|c|}{ Cultivated } \\
\hline Triticum dicoccum & c & · & $\cdot$ & 1 & $\cdot$ & $\cdot$ & $\cdot$ & $\cdot$ & $\cdot$ & · & $\cdot$ & $\cdot$ & $\cdot$ & $\cdot$ & $\cdot$ & $\cdot$ & $\cdot$ & $\cdot$ & $\cdot$ & $\cdot$ & $\cdot$ & $\cdot$ & $\cdot$ & · & $\cdot$ \\
\hline Triticum dicoccum & gb & $\cdot$ & $\cdot$ & 1 & . & . & $\cdot$ & $\cdot$ & $\cdot$ & $\cdot$ & . & $\cdot$ & $\cdot$ & . & . & . & . & . & $\cdot$ & . & . & $\cdot$ & $\cdot$ & . & . \\
\hline Triticum monococcum & $\mathrm{c}$ & . & $\cdot$ & 1 & . & . & $\cdot$ & $\cdot$ & . & . & . & . & . & . & . & . & . & . & $\cdot$ & $\cdot$ & . & . & . & . & . \\
\hline $\begin{array}{l}\text { Triticum dicoccum/ } \\
\text { monococcum }\end{array}$ & $\mathrm{gb}$ & $\cdot$ & · & $\cdot$ & $\cdot$ & $\cdot$ & . & . & · & · & · & . & $\cdot$ & . & $\cdot$ & . & . & 1 & · & · & · & $\cdot$ & $\cdot$ & $\cdot$ & · \\
\hline Triticum sp. & $\mathrm{c}$ & $\cdot$ & $\cdot$ & $\cdot$ & $\cdot$ & 1 & $\cdot$ & · & $\cdot$ & $\cdot$ & $\cdot$ & $\cdot$ & $\cdot$ & $\cdot$ & 1 & $\cdot$ & $\cdot$ & $\cdot$ & $\cdot$ & $\cdot$ & $\cdot$ & $\cdot$ & $\cdot$ & $\cdot$ & · \\
\hline Ttriticum sp. & $\mathrm{gb}$ & 4 & $\cdot$ & 1 & $\cdot$ & $\cdot$ & $\cdot$ & . & · & $\cdot$ & . & . & $\cdot$ & $\cdot$ & $\cdot$ & $\cdot$ & · & $\cdot$ & $\cdot$ & $\cdot$ & $\cdot$ & $\cdot$ & $\cdot$ & . & . \\
\hline Panicum miliaceum & $\mathrm{c}$ & . & . & . & 1 & . & . & . & . & . & 1 & . & . & . & . & . & . & . & . & . & . & . & . & . & . \\
\hline cf. Panicum miliaceum & $\mathrm{c}$ & . & $\cdot$ & . & . & . & . & . & . & . & . & 3 & . & . & . & 1 & 1 & . & . & 1 & . & . & . & . & . \\
\hline Panicoidaceae & $\mathrm{c}$ & . & . & . & . & . & . & . & . & . & . & $\cdot$ & . & . & . & $\cdot$ & $\cdot$ & . & . & 1 & . & . & . & . & . \\
\hline Pisum / Vicia & $\mathrm{s}$ & $\cdot$ & $\cdot$ & . & . & . & . & 1 & $\cdot$ & $\cdot$ & . & $\cdot$ & $\cdot$ & . & . & . & . & . & . & . & $\cdot$ & . & . & . & . \\
\hline Fabaceae indet. & $\mathrm{s}$ & . & $\cdot$ & $\cdot$ & 1 & . & . & . & $\cdot$ & $\cdot$ & . & 1 & $\cdot$ & 4 & . & 1 & . & $\cdot$ & . & . & $\cdot$ & . & $\cdot$ & . & . \\
\hline Cerealia indet. & $\mathrm{c}$ & . & $\cdot$ & 1 & . & 2 & . & . & . & . & . & $\cdot$ & 2 & 1 & . & $\cdot$ & . & 1 & . & . & . & . & . & . & . \\
\hline \multicolumn{26}{|l|}{ Ruderal } \\
\hline Chenopodium t. album & $\mathrm{s}$ & . & $25^{*}$ & 1 & $\cdot$ & $\cdot$ & 1 & $\cdot$ & $\cdot$ & $\cdot$ & $1^{*}$ & $1 *$ & $1 *$ & $\cdot$ & $\cdot$ & 10 & $\cdot$ & 1 & 1 & $\cdot$ & $\cdot$ & $31^{*}$ & $\cdot$ & $\cdot$ & $\cdot$ \\
\hline Chenopodium sp. & $\mathrm{s}$ & $\cdot$ & $\cdot$ & $\cdot$ & . & . & $\cdot$ & $\cdot$ & $\cdot$ & $\cdot$ & $\cdot$ & $\cdot$ & $\cdot$ & . & $\cdot$ & $\cdot$ & . & $\cdot$ & $\cdot$ & . & $\cdot$ & $5^{*}$ & . & $1^{*}$ & . \\
\hline Chenopodiaceae indet. & $\mathrm{s}$ & $\cdot$ & $\cdot$ & $\cdot$ & $\cdot$ & $\cdot$ & $\cdot$ & $\cdot$ & $\cdot$ & · & · & $\cdot$ & $\cdot$ & $\cdot$ & $\cdot$ & . & . & $\cdot$ & $\cdot$ & $\cdot$ & $\cdot$ & $\cdot$ & · & $\cdot$ & . \\
\hline cf. Chenopodium & $\mathrm{s}$ & $\cdot$ & $\cdot$ & . & . & $\cdot$ & $\cdot$ & . & $\cdot$ & $\cdot$ & . & $\cdot$ & . & 1 & . & . & . & $\cdot$ & $\cdot$ & $\cdot$ & . & $\cdot$ & . & . & . \\
\hline Melandrium / Silene & $\mathrm{s}$ & . & $\cdot$ & . & . & . & . & . & $\cdot$ & $\cdot$ & . & $\cdot$ & $\cdot$ & . & . & . & . & $\cdot$ & $\cdot$ & $\cdot$ & $\cdot$ & 1 & $\cdot$ & . & . \\
\hline Polygonum lapathifolium & $f$ & . & . & . & . & . & . & . & . & . & 1 & . & . & . & . & . & . & . & . & . & . & . & . & . & . \\
\hline Polygonum sp. & $f$ & . & $\cdot$ & . & . & . & $\cdot$ & $\cdot$ & . & . & . & . & . & . & . & . & $\cdot$ & $1^{*}$ & . & . & . & . & . & . & . \\
\hline Fallopia convulvulus & $f$ & . & $\cdot$ & . & . & 1 & . & . & $\cdot$ & $\cdot$ & . & . & . & . & . & . & $\cdot$ & $\cdot$ & . & . & $\cdot$ & 1 & . & . & . \\
\hline cf. Valenariella & $f$ & $\cdot$ & 1 & $\cdot$ & . & $\cdot$ & . & . & . & $\cdot$ & . & $\cdot$ & . & . & $\cdot$ & . & $\cdot$ & $\cdot$ & $\cdot$ & . & $\cdot$ & . & . & . & . \\
\hline \multicolumn{26}{|c|}{ Grassland / meadow / pasture } \\
\hline Brasicaceae indet. & $\mathrm{s}$ & $\cdot$ &. & $\cdot$ & $\cdot$ & $\cdot$ & $\cdot$ & $\cdot$ & $\cdot$ & $\cdot$ & $\cdot$ & 1 & $\cdot$ & $\cdot$ & $\cdot$ & $\cdot$ & $\cdot$ & $\cdot$ & $\cdot$ & $\cdot$ & $\cdot$ & $\cdot$ & $\cdot$ & $\cdot$ & $\cdot$ \\
\hline Coronilla varia & $\mathrm{s}$ & . & . & . & . & . & . & . & . & . & . & . & . & . & . & 1 & . & . & . & . & . & . & . & . & . \\
\hline Hypericum perforatum & $\mathrm{s}$ & . & . & . & . & . & . & . & . & . & . & . & . & . & . & . & . & . & 1 & . & . & . & . & . & . \\
\hline Plantago laceolata & $\mathrm{s}$ & . & $\cdot$ & . & . & . & . & $\cdot$ & $\cdot$ & . & . & . & . & . & . & . & $\cdot$ & . & $\cdot$ & $\cdot$ & $\cdot$ & . & . & . & 1 \\
\hline Plantago media & $\mathrm{s}$ & $\cdot$ & $\cdot$ & . & . & . & . & $\cdot$ & . & $\cdot$ & . & . & $\cdot$ & 1 & . & $\cdot$ & $\cdot$ & $\cdot$ & $\cdot$ & $\cdot$ & $\cdot$ & . & . & . & . \\
\hline Poaceae t. Poa & $\mathrm{c}$ & $\cdot$ & $\cdot$ & . & . & $\cdot$ & . & $\cdot$ & $\cdot$ & . & . & $\cdot$ & $\cdot$ & $\cdot$ & . & . & 1 & 1 & $\cdot$ & . & . & $\cdot$ & . & . & . \\
\hline Rumex acetosella & $\mathrm{f}$ & $\cdot$ & $\cdot$ & . & $\cdot$ & . & $\cdot$ & . & . & . & 1 & . & $\cdot$ & . & . & . & . & 3 & $\cdot$ & $\cdot$ & . & . & . & . & . \\
\hline cf. Rumex acetosella & $f$ & $\cdot$ & . & $\cdot$ & . & . & . & $\cdot$ & $\cdot$ & $\cdot$ & . & 1 & $\cdot$ & . & . & · & $\cdot$ & $\cdot$ & $\cdot$ & $\cdot$ & . & 1 & . & . & . \\
\hline Rosaceae cf. Rubus & $f$ & . & . & . & . & . & . & . & . & . & . & . & . & . & . & . & . & $\cdot$ & . & . & . & . & . & . & . \\
\hline Stellaria graminea & $\mathrm{s}$ & $\cdot$ & . & . & . & . & . & . & $\cdot$ & . & . & $\cdot$ & $\cdot$ & . & . & . & $\cdot$ & $\cdot$ & . & . & . & 1 & . & . & . \\
\hline cf. Rubiaceae & $\mathrm{f}$ & $\cdot$ & . & . & . & . & . & $\cdot$ & . & $\cdot$ & . & $\cdot$ & $\cdot$ & . & . & . & $\cdot$ & . & $\cdot$ & $\cdot$ & . & 1 & . & . & . \\
\hline cf. Viola & $f$ & $\cdot$ & $\cdot$ & $\cdot$ & . & . & . & . & . & $\cdot$ & $\cdot$ & . & $\cdot$ & . & . & $\cdot$ & . & . & 1 & . & . & $\cdot$ & . & $\cdot$ & . \\
\hline \multicolumn{26}{|l|}{ Other } \\
\hline cf. Geranium & $\mathrm{s}$ & · & $\cdot$ & $\cdot$ & $\cdot$ & $\cdot$ & 1 & $\cdot$ & $\cdot$ & $\cdot$ & $\cdot$ & $\cdot$ & $\cdot$ & $\cdot$ & $\cdot$ & $\cdot$ & $\cdot$ & $\cdot$ & $\cdot$ & $\cdot$ & $\cdot$ & $\cdot$ & $\cdot$ & $\cdot$ & . \\
\hline cf. Lamiaceae & $\mathrm{f}$ & . & $\cdot$ & . & . & . & . & . & $\cdot$ & . & . & . & . & . & . & 1 & . & . & . & . & . & . & 1 & . & . \\
\hline Poaceae & c & . & $\cdot$ & 2 & . & . & $\cdot$ & . & $\cdot$ & $\cdot$ & . & . & . & . & . & . & 1 & 8 & $\cdot$ & $\cdot$ & . & $\cdot$ & 3 & . & . \\
\hline Bud & & . & 1 & $\cdot$ & . & . & . & $\cdot$ & $\cdot$ & $\cdot$ & . & . & $\cdot$ & . & $\cdot$ & . & $\cdot$ & $\cdot$ & $\cdot$ & $\cdot$ & $\cdot$ & . & $\cdot$ & . & . \\
\hline Indetermination & & . & 4 & 6 & 2 & 2 & 5 & . & 7 & 5 & 3 & 8 & 3 & 3 & 1 & 4 & 4 & 40 & 3 & 8 & . & 6 & 9 & 1 & 4 \\
\hline Cenococcum & & . & . & . & 2 & . & 1 & . & . & . & . & 20 & . & . & . & . & . & $\cdot$ & $\cdot$ & . & . & . & . & . & \\
\hline
\end{tabular}

2005; Lityńska-Zając and Wasylikowa, 2005; Mueller-Bieniek and Woch, 2012). There are specific species that could be assigned to more than one of the ecological groups. For example, field sorrel (Rumex acetosella), can be classified as a plant of meadows and pastures or a ruderal plant. But, for clarity, each species from Pielgrzymowice 9 is assigned to only one group according to Mueller-Bieniek and Woch (2012). 
Cultivated plants were represented by finds of chaff and caryopses of emmer wheat (Triticum diccocum), einkorn wheat (Triticum monococcum), wheat (Triticum sp.) and common millet (Panicum miliaceum) (Table 1). A dozen or so heavily damaged caryopsis fragments were included in the category of cereals (Cerealia indet.). These are usually fragments with parts of the furrow or embryo preserved. Most likely these were remains of wheat or barley. Feature 678 provided two caryopses, one of emmer wheat ( $T$. dicoccum) and one einkorn (T. monococcum), one chaff of emmer wheat, and one glume bases of indeterminate wheat (Triticum sp.). Single cereal caryopsis (Cerealia indet.) was found in features 202, 392, 785, 678 and 681. Common millet (Panicum miliaceum) was represented by two grains from features 202 and 281. Five damaged caryopses, similar to millet (cf. Panicum miliaceum) in shape and size were also found. Seeds of pea or vetch or faba beans (Pisum/Vicia) were also identified, but could not be distinguished due to poor condition and the lack of seed coat.

Ruderal and/or segetal plants were represented at Pielgrzymowice site 9 by several taxa (Table 1), such as fat-hen (Chenopodium type album), black-bindweed (Fallopia convulvulus), knotweed (Polygonum lapathifolium) or a specimen similar to lamb's lettuce (cf. Valenariella sp.). The most numerous species from this group was fat-hen (Chenopodium album) 14 seeds of which were found in samples from features 678, 146, 646, 392 and 123.

Meadow/pasture plants were represented by 11 species (Table 1). Single remains were found in seven features, including crownvetch (Coronilla varia), field sorrel (Rumex acetosella), St. John's wort (Hypericum perforatum), ribwort plantain (Plantago lanceolata), medium plantain (Plantago media) and common starwort (Stellaria graminea). Features 669 and 392 provided two caryopses of the genus Poa sp. The single seeds of ribwort plantain (Plantago lanceolata) and hoary plantain (Plantago media) were found in features 139 and 681 respectively. Four specimens of field sorrel (Rumex acetosella) (one in feature 281 and three in feature 669) were also identified.

The remaining plant remains mainly represented 14 caryopses of grasses (Poaceae), one Geranium sp. seed from feature 146, two cf. Lamiaceae seeds from features 646, 496 and 23, Fabaceae from features 202, 787, 681,
646, Cenococcum sclerotium, found in features 202, 192 and 787. Small-grained grasses were found in multiple features ( 8 specimens in feature 392 and single specimens in features 496, 669 and 678). Most of the caryopses of grasses were difficult to precisely identify due to their damaged structure. There were also 121 unspecified plant remains from various features.

\section{DISCUSSION}

Finds of cereals and ruderal plants at the Pielgrzymowice site 9 suggest that cultivated plants formed part of the diet of the people of this settlement. Cereals were the main crops grown in most of the Old World civilizations. Due to their calorific value, they were a good source of food for humans (Zohary and Hopf, 2000). Usually at archaeological sites, the most common remains are naked grains, spikelet forks, and glume bases (Lityńska-Zając and Wasylikowa, 2005) while rachis internodes are scarcely found. In Pielgrzymowice at least three cereal species were used: Triticum diccocum, Triticum monococcum, and Panicum miliaceum (Table 1; Fig. 2).

These crops were also often found at other Trzciniec culture sites. Emmer wheat was identified at seven sites. Most specimens were preserved at site $\mathrm{G}$ in Słonowice (Table 2). Remains of einkorn wheat were also found at Lipnik site 5, Słonowice site G, Jakuszowice site 2 and Miechów site 3 (Table 2). Millet appeared at Słonowice site G (320 specimens) and in great numbers at Lipnik site 5 (2070 specimens) (Table 2).

It is not easy to compare Trzciniec culture plant assemblages from Lesser Poland, because they differ greatly in terms of the quantity of carpological remains. The archaeobotanically sampled archeological sites of the Trzciniec culture can be divided into 3 groups: (1) sites with a high number of plant remains and a high taxonomic diversity, but mostly deposited in a single feature, including Lipnik site 5 (Bieniek, 2008; Kapcia and MuellerBieniek, 2019) and Słonowice site G (LityńskaZając and Makowicz-Poliszot, 2019); (2) sites with relatively low number of plant remains, including Pielgrzymowice site 9, Miechów site 3 (Kapcia, unpublished), Jakuszowice site 2 (Lityńska-Zając, 1999), Iwanowice-Babia Góra 

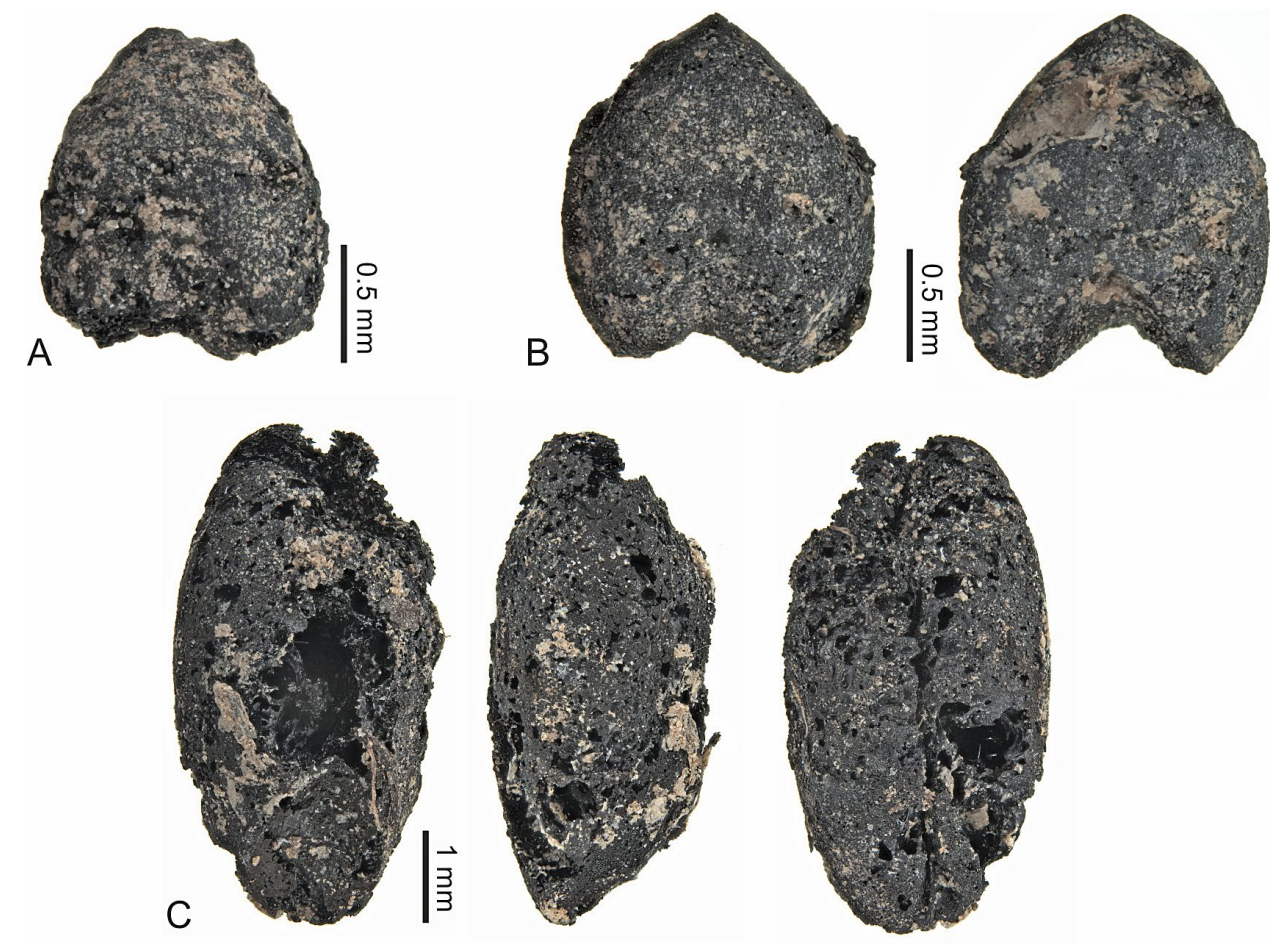

Fig. 2. The Middle Bronze Age, charred plant macro-remains from Pielgrzymowice site 9, cultivated. A. cf. Panicum sp.; B. Panicum miliaceum; C. Triticum sp.

(Lityńska-Zając, 1994), Smroków 17 (LityńskaZając, 2010), Słonowice site 4 (Calderoni et al., 1998-2000) and Kazimierza Mała (only plant impressions were recorded in Kazimierza Mała) (Kruk et al., 2016). The Białobrzegi 8 site can also be included in this group, because in 8 archaeobotanical samples only three fathen seeds (Chenopodium t. album) were found (Kapcia, unpublished); (3) sites that were archaeobotanicaly sampled, but did not provide any plant remains, such as Pawłosiów site 2 (Podkarpackie Province), Wola Mała site 17 (Czarna, Podkarpackie Province) and Chotyniec site 36 (Podkarpackie Province) (Kapcia, unpublished). We are not able to determine whether the lack of any plant debris from "empty samples" sites is the result of a small number of samples taken, the small volume of samples (100-500 ml), the method of their collection or preservation conditions. Usually, the total volume of samples taken has a direct impact on the amount of plant remains found. The smaller is the volume of samples taken, the smaller the number of plant remains will be, especially in dry open sediments.

Emmer wheat and einkorn are the most commonly found cereals in the Trzciniec sites. Wheat is superior among cereals in terms of nutritional value and a significant amount of gluten contained in the endosperm of grains, which is responsible for better rheological properties than that observed in other cereals (Zohary and Hopf, 2000; Jankowska et al., 2011). Emmer wheat belongs to the tetraploid wheat group (number of chromosomes $2 \mathrm{n}=28$ ). The emmer's ear does not fall apart spontaneously. It is hulled wheat, undemanding to soil and resistant to drought. It is related to the wild flat wheat (Triticum dicoccoides) (LityńskaZając and Wasylikowa, 2005; Peng et al., 2011). Emmer was the main crop grown in the Middle East in the Neolithic age. It often appeared in cultivation with barley or einkorn, always as the dominant cereal. Its importance decreased in the Bronze Age in the Middle East, while in Poland and the rest of Europe it was the most commonly cultivated species throughout the Neolithic and Bronze Age periods. Its significance decreased in the early Iron Age (LityńskaZając and Wasylikowa, 2005). Einkorn wheat (Triticum monococcum) belongs to the diploid wheat group ( $2 \mathrm{n}=14$ chromosomes). It is a frostresistant plant, undemanding, and it can grow on poorer soils. Compared to emmer and spelt wheat, it is abundant in proteins, carotenoids, tocols, free phenolic acids, and trace minerals (Hidalgo and Brandolini, 2014). The structure of the grain is quite distinctive compared to other grains. It has delicate ears and spikelets (Zohary and Hopf, 2000; Lityńska-Zając and Wasylikowa, 2005). In Poland, einkorn finds are common through the Neolithic period, while 
Table 2. Remains of cultivated plants from Trzciniec culture sites (southern Poland): ch - charred remains, sb - spiklet bases, gb - glume bases, c - caryopsis, grain, s - seed

\begin{tabular}{|c|c|c|c|c|c|c|c|c|c|c|}
\hline Plant name & 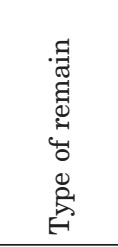 & 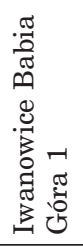 & 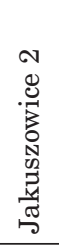 & 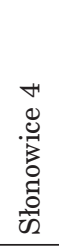 & 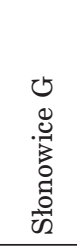 & 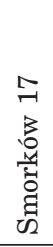 & 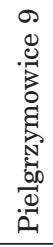 & 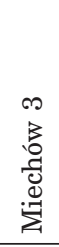 & 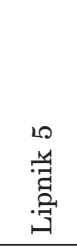 & 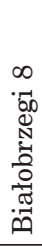 \\
\hline Hordeum vulgare & $\mathrm{c}$ & . & 19 & 10 & 1928 & $\cdot$ & $\cdot$ & . & 9 & $\cdot$ \\
\hline Hordeum vulgare & gb & . & $\cdot$ & $\cdot$ & 1 & · & . & $\cdot$ & $\cdot$ & $\cdot$ \\
\hline cf Hordeum vulgare (naked) & $\mathrm{c}$ & . & . & $\cdot$ & $\cdot$ & · & . & $\cdot$ & 4 & · \\
\hline Panicum miliaceum & Spiklet & . & . & . & 22 & . & . & . & $\cdot$ & . \\
\hline Panicum miliaceum & gb & $\cdot$ & $\cdot$ & $\cdot$ & 21 & $\cdot$ & $\cdot$ & $\cdot$ & $\cdot$ & $\cdot$ \\
\hline Panicum miliaceum & $\mathrm{c}$ & . & $\cdot$ & . & 320 & . & 2 & . & 2070 & . \\
\hline cf. Panicum miliaceum & c & · & $\cdot$ & $\cdot$ & $\cdot$ & $\cdot$ & 6 & $\cdot$ & $\cdot$ & $\cdot$ \\
\hline Triticum aestivum & $\mathrm{c}$ & . & 2 & $\cdot$ & 168 & . & $\cdot$ & $\cdot$ & $\cdot$ & $\cdot$ \\
\hline Triticum dicoccon & $\mathrm{c}$ & 15 & 35 & 11 & 238 & 6 & 1 & 2 & 5 & $\cdot$ \\
\hline Triticum dicoccon & $\mathrm{sb}$ & $\cdot$ & $\cdot$ & 1 & 72 & $\cdot$ & $\cdot$ & $\cdot$ & 2 & $\cdot$ \\
\hline Triticum dicoccon & gb & . & . & $\cdot$ & 66 & . & 1 & 3 & 12 & . \\
\hline Triticum monococcum & $\mathrm{c}$ & . & 1 & . & 2 & . & 1 & 1 & 4 & . \\
\hline Triticum monococcum & gb & . & $\cdot$ & . & 1 & . & $\cdot$ & $\cdot$ & $\cdot$ & . \\
\hline Triticum monососсит & $\mathrm{sb}$ & $\cdot$ & $\cdot$ & $\cdot$ & $\cdot$ & . & 1 & $\cdot$ & 9 & $\cdot$ \\
\hline Triticum dicoccon/T. monococcum & $\mathrm{sb}$ & 1 & $\cdot$ & $\cdot$ & 9 & . & · & · & $\cdot$ & $\cdot$ \\
\hline Triticum dicoccon/T. monococcum & $\mathrm{c}$ & $\cdot$ & $\cdot$ & 5 & 10 & . & . & $\cdot$ & $\cdot$ & $\cdot$ \\
\hline Triticum dicoccon/T. monococcum & Spiklet & · & $\cdot$ & $\cdot$ & 1 & · & $\cdot$ & $\cdot$ & $\cdot$ & $\cdot$ \\
\hline Triticum dicoccon/T. monococcum & $\mathrm{sb}$ & . & . & . & 8 & . & 1 & . & . & . \\
\hline Triticum spelta & $\mathrm{c}$ & . & . & . & 4 & . & $\cdot$ & . & 2 & . \\
\hline Triticum spelta & $\mathrm{sb}$ & . & . & · & 1 & . & . & . & 1 & · \\
\hline Triticum spelta & gb & · & $\cdot$ & · & 1 & . & . & . & 10 & · \\
\hline Triticum sp. & $\mathrm{c}$ & . & 19 & $\cdot$ & 12 & . & 2 & 1 & 326 & $\cdot$ \\
\hline Triticum sp. & $\mathrm{sb}$ & . & $\cdot$ & $\cdot$ & $\cdot$ & $\cdot$ & 5 & 1 & 26 & $\cdot$ \\
\hline Triticum sp. & gb & $\cdot$ & $\cdot$ & $\cdot$ & $\cdot$ & $\cdot$ & . & $\cdot$ & 199 & · \\
\hline Cerealia indet. & $\mathrm{c}$ & 18 & 40 & 40 & 796 & . & 7 & 27 & 134 & . \\
\hline Lens culinaris & $\mathrm{c}$ & $\cdot$ & $\cdot$ & $\cdot$ & 4 & $\cdot$ & . & $\cdot$ & $\cdot$ & · \\
\hline P. sativum / V. faba & $\mathrm{s}$ & . & . & . & 4 & . & . & . & . & . \\
\hline Pisum sativum & $\mathrm{s}$ & · & . & . & 125 & $\cdot$ & . & . & . & . \\
\hline Pisum sativum / Vicia sativa & $\mathrm{s}$ & . & . & $\cdot$ & 1 & $\cdot$ & $\cdot$ & 1 & · & . \\
\hline Pisum sp. / Vicia sp. & $\mathrm{s}$ & . & . & $\cdot$ & $\cdot$ & $\cdot$ & 1 & $\cdot$ & $\cdot$ & $\cdot$ \\
\hline
\end{tabular}

in the Bronze Age and later periods its significance decreased (Lityńska-Zając and Wasylikowa, 2005). Emmer wheat and einkorn are often found together.

Millet remains found in features 651, 678, 202, 281 at Pielgrzymowice site 9, prove, among finds from other sites, that the people of the Trzciniec culture cultivated this cereal. The largest millet find from the Trzciniec culture up to date, comes from pit 302 from Lipnik site 5, which produced 2070 grains. Considering the size of millet grains compared to wheat caryopses or acorns, which were also recorded at the same pit, it is a relatively small volume of food or fodder. It corresponds in size to a meal for one adult person. Millet is scarce in archaeobotanical samples dated to the Middle Bronze Age, even more in the Trzciniec culture context
(Table 2). Lipnik site 5 is the only large deposit of this crop in Poland so far that gave ${ }^{14} \mathrm{C}$ dates: Poz-103203, $3040 \pm 35{ }^{14} \mathrm{C}$ (AMS method) (Kapcia and Mueller-Bieniek, 2019). In other sites, it is usually found in the form of grains or imprints on vessels (Motuzaite-Matuzeviciute et al., 2013). The oldest finds of millet come from early Neolithic sites, but in all studied cases, ${ }^{14} \mathrm{C}$ dating changed their chronology. For example, the oldest find of millet from an intact Neolithic layer from the Fajsz 18 site (Hungary) associated with the Sopot culture was proven to be much younger. The site was dated to the 6 th millennium BC, while the date obtained from millet grains was more than three thousand years younger (AMS OxA-26.704, $3214 \pm 36$ ${ }^{14} \mathrm{C}$, after calibration $95.4 \% 1606-1414$ cal. BC) (Motuzaite-Matuzeviciute et al., 2013; Kapcia 
and Mueller-Bieniek, 2019). At Miechów site 3 , millet (Panicum miliaceum) was identified in a feature of the Lublin-Volhynian culture belonging to the Lengyel-Polgár cultural complex, but according to ${ }^{14} \mathrm{C}$ dating, it came from the Late Bronze Age $(2745 \pm 30$ BP, Poz-83231, 974BC-819BC with $95.4 \%$ probability) (Mueller-Bieniek et al., 2018). In this context, it is not surprising that most of the younger (Neolithic) single millet finds were interpreted as weeds (Lityńska-Zając and Wasylikowa, 2005; Zohary and Hopf, 2000) or post-deposition disorders (Motuzaite-Matuzeviciute et al., 2013; MuellerBieniek et al., 2018). Archaeological finds indicate that millet was known in Europe from the second half of the 2nd millennium BC, at the time of great social and economic changes. The cultivation of millet in Europe probably began earlier, as early as the 16th century BC, and spread rapidly at the turn of the 15 th and 14 th centuries BC. Its short vegetation period and growth under various conditions allowed for additional harvests and thus surplus food/feed. In the food supply system of that time, based mainly on winter cereals, it was a major innovation that enabled the development of agriculture (Filipović et al., 2020). Common millet (Panicum miliaceum) is a cereal that does well in changing conditions. It can grow in a variety of soils, even poor ones, except for dry sands and wet soils. It is sensitive to frost therefore its growth, flowering, and maturation period are limited to three months from mid-May to August (Lityńska-Zając and Wasylikowa, 2005). It can be cultivated on unmanaged and previously uncultivated lands (so-called "nowina") (Strzelczyk, 2003; Kapcia and Mueller-Bieniek, 2019). The cutting of millet probably had to be done in a way preventing small grains from falling off. According to modern data, this can be done in three ways: cutting the stem next to the panicle, cutting it near the ground, or pulling the entire plant out (Strzelczyk, 2003). Of course, based on finds from only three sites, we cannot determine the extent to which the population associated with the Trzciniec culture cultivated millet, but we can indicate that it could be as important as other types of grain (wheat or barley) found at other archaeological sites. However, millet found in Pielgrzymowice can turn out to be one of the earliest finds of this cereal species in Poland (assuming correct relative dating of features). It would demonstrate that significant changes in cultivation strategy, so far based mostly on hulled wheat species, were initiated in Lesser Poland.

Other species that were identified at Trzciniec sites were not observed at Pielgrzymowice site 9 . They include common wheat (Triticum aestivum) (found at Jakuszowice site 2 and Słonowice site G), spelt (Triticum spelta) (Słonowice site G and Lipnik site 5) and barley (Hordeum vulgare) (Jakuszowice site 2, Słonowice site 4 and G and Lipnik site 5) (Table 2). This does not mean, however, that the people living in Pielgrzymowice settlement did not know these cereals. Also at other sites, there were cereal remains in the form of grains and glume base and spikelet forks (Table 2) while at Pielgrzymowice only grains and glum bases were found (Table 1 and 2).

Ruderal and segetal plant remains are common at Trzciniec culture sites. Multiple charred seeds of Chenopodium t. album were identified in Pielgrzymowice 9 samples (14 specimens). They also appeared in great numbers at Lipnik site 5 (755 specimens) (Kapcia and Mueller-Bieniek, 2019) and Słonowice site G (545 specimens). Much less were found at Miechów 3 (2 specimens - Kapcia, unpublished), Białobrzegi 8 (3 specimens) (Kapcia, unpublished) and Jakuszowice site 2 (single specimen) (Lityńska-Zając, 1999) (Table 3). At Pielgrzymowice 9 two Fallopia convulvulus fruits were identified. Single fruit of Fallopia convulvulus was also recorded at Jakuszowice 2 (Lityńska-Zając, 1999), 89 specimens at Słonowice site G (Lityńska-Zając and Makowicz-Poliszot, 2019) and 30 at Lipnik site 5 (Bieniek, 2008; Kapcia and Mueller-Bieniek, 2019). Interestingly, fat-hen and black-bindweed were also edible plants (Behre, 2008), which could supplement the diet in times of need (Mueller-Bieniek et al., 2020) (Table 3).

The presence of meadow/grassland plant remains related with pasture plants at Trzciniec culture sites indicates that they were part of the Middle Bronze Age palaeoeconomy, although it is also possible that they were accidentally deposited in the features. They could be used as animal fodder, bedding material, or for medical purposes. At the Pielgrzymowice site 9 only single remains of lesser stichwort (Stellaria graminea), ribwort plantain (Plantago lanceolata), crownvetch (Coronilla varia), violet (Viola sp.) and hoary plantain (Plantago media) were found (Fig. 3). Pasture plant remains from other Trzciniec culture sites provide much more data 
Table 3. Remains of ruderal and/or segetal plants from Trzciniec culture sites (southern Poland): ch - charred remains, c caryopsis, grain, $\mathrm{s}-$ seed, $\mathrm{f}$ - fruit

\begin{tabular}{|c|c|c|c|c|c|c|c|c|c|c|}
\hline Plant name & 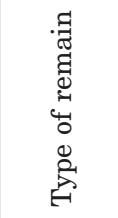 & 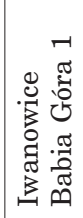 & 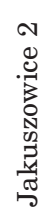 & 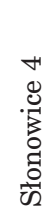 & 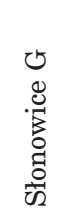 & 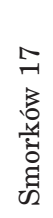 & 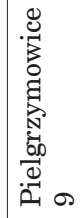 & 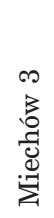 & 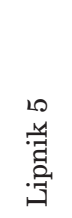 & 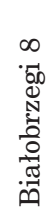 \\
\hline Agrostemma githago & $\mathrm{s}$ & . & . & . & 6 & . & . & . & . & . \\
\hline Anthemis arvensis & $\mathrm{f}$ & . & . & . & 1 & · & . & . & . & · \\
\hline Artemisia vulgaris & $\mathrm{f}$ & . & . & . & 11 & . & . & . & . & . \\
\hline Avena sp. & $\mathrm{c}$ & . & . & . & $\cdot$ & . & . & . & 4 & . \\
\hline Bromus arvensis & $\mathrm{c}$ & . & . & . & 1 & . & . & . & . & . \\
\hline Bromus secalinus & $\mathrm{c}$ & 1 & . & . & 17 & . & . & $\cdot$ & $\cdot$ & $\cdot$ \\
\hline Bromus sp. & c & 4 & . & . & 40 & . & . & . & 9 & . \\
\hline Centaurea cyanus & $\mathrm{f}$ & . & . & . & 1 & . & . & . & $\cdot$ & . \\
\hline Chenopodium t. album & $\mathrm{s}$ & . & 1 & . & 545 & . & 14 & 2 & 755 & 3 \\
\hline Chenopodium ficifolium & $\mathrm{s}$ & . & . & . & 5 & . & $\cdot$ & . & $\cdot$ & . \\
\hline Chenopodium hybridum & $\mathrm{s}$ & . & . & . & 1 & . & . & . & . & . \\
\hline Chenopodium murale & $\mathrm{s}$ & . & . & . & 4 & . & . & . & . & . \\
\hline Chenopodium opulifolium & $\mathrm{s}$ & . & . & . & 10 & . & . & . & . & . \\
\hline Chenopodium polyspermum & $\mathrm{s}$ & . & . & . & 4 & . & . & . & . & . \\
\hline Chenopodium urbicum & $\mathrm{s}$ & . & . & . & 2 & . & . & . & . & . \\
\hline Chenopodium sp. & $\mathrm{s}$ & . & . & . & 28 & . & . & . & $\cdot$ & . \\
\hline Digitaria ischaemum & $\mathrm{c}$ & . & . & . & 7 & . & . & . & 3 & . \\
\hline Digitaria sanguinalis & $\mathrm{c}$ & . & . & . & 2 & . & . & . & $\cdot$ & . \\
\hline Digitaria sp. & $\mathrm{c}$ & . & . & . & $\cdot$ & . & . & . & 288 & . \\
\hline Elymus repens & $\mathrm{c}$ & . & . & . & 1 & . & . & . & $\cdot$ & . \\
\hline Echinochloa crus-galli & $\mathrm{c}$ & . & . & . & 35 & . & . & 1 & 151 & . \\
\hline Euphorbia helioscopia & $\mathrm{f}$ & . & . & . & 3 & . & . & . & $\cdot$ & . \\
\hline Fallopia convulvulus & $\mathrm{f}$ & . & 1 & . & 89 & . & 2 & . & 30 & . \\
\hline Fallopia dumentorum & $\mathrm{f}$ & . & . & . & 1 & . & . & . & $\cdot$ & . \\
\hline Fumaria officinalis & $\mathrm{f}$ & . & . & . & 1 & . & . & . & . & . \\
\hline Galeopsis cf tetrahit & $f$ & . & . & . & . & . & . & . & 2 & . \\
\hline Galium aparine & $f$ & . & . & . & 4 & . & . & . & 3 & . \\
\hline Galium sp. (small) & $f$ & . & . & . & . & . & . & . & 3 & . \\
\hline Galium spurium & $\mathrm{f}$ & . & . & . & 8 & . & . & . & . & . \\
\hline Lamium album & $s$ & . & . & . & 1 & . & . & . & . & . \\
\hline Lapsana communis & $\mathrm{f}$ & . & . & . & 2 & . & . & . & . & . \\
\hline Lithospermum arvense & $\mathrm{f}$ & . & . & . & 7 & . & . & . & . & . \\
\hline Melandrium album / Silene & $\mathrm{s}$ & . & . & . & . & . & 1 & . & . & . \\
\hline Melandrium noctiflorum & $\mathrm{s}$ & . & . & . & 6 & . & . & . & . & . \\
\hline Myosotis arvensis & $\mathrm{f}$ & . & . & . & 4 & . & . & . & . & . \\
\hline Myosotis sp. & $\mathrm{f}$ & . & . & . & . & . & . & . & 1 & . \\
\hline Nepeta cataria & $\mathrm{f}$ & . & . & . & 1 & . & . & . & . & . \\
\hline Nepeta pannonica & $\mathrm{f}$ & . & . & . & 1 & . & . & . & $\cdot$ & . \\
\hline Panicoidaceae & $\mathrm{c}$ & . & . & . & 127 & . & . & . & 92 & . \\
\hline Papaver argemone & $\mathrm{s}$ & . & . & . & 1 & . & . & . & $\cdot$ & . \\
\hline Papaver rhoeas & $\mathrm{s}$ & . & . & . & 1 & . & . & . & . & . \\
\hline Plantago arenaria & $\mathrm{s}$ & . & . & . & 3 & . & . & . & . & . \\
\hline Polygonum aviculare & $\mathrm{f}$ & . & . & . & 4 & . & . & . & 8 & . \\
\hline Polygonum lapathifolium & $\mathrm{f}$ & . & . & . & 1 & . & 1 & . & . & . \\
\hline $\begin{array}{l}\text { Polygonum lapathifolium } \\
\text { subsp. lapathifolium }\end{array}$ & $\mathrm{f}$ & . & . & . & 1 & . & . & $\cdot$ & . & . \\
\hline Polygonum persicaria & $\mathrm{s}$ & . & $\cdot$ & . & 15 & . & . & . & 247 & . \\
\hline Polygonum sp. & $\mathrm{s}$ & . & 1 & . & 9 & . & . & . & 133 & . \\
\hline Rumex crispus & $\mathrm{f}$ & . & . & . & 2 & . & . & . & $\cdot$ & . \\
\hline Sambucus ebulus & $\mathrm{s}$ & . & . & . & 6 & . & . & . & . & . \\
\hline Scleranthus annus/perennis & $\mathrm{f}$ & . & . & . & 1 & . & . & . & 3 & . \\
\hline Setaria pumila & Spiklet & . & . & . & 29 & . & . & . & . & . \\
\hline
\end{tabular}


Table 3. Continued

\begin{tabular}{|c|c|c|c|c|c|c|c|c|c|c|}
\hline Plant name & 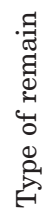 & 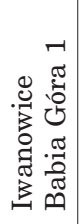 & 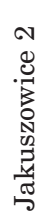 & 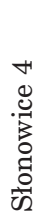 & 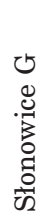 & 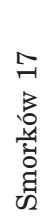 & 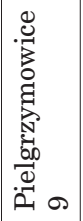 & 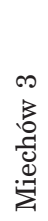 & 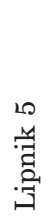 & 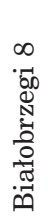 \\
\hline Setaria pumila & $\mathrm{c}$ & . & . & . & 27 & . & . & . & . & $\cdot$ \\
\hline Setaria viridis / verticillata & $\mathrm{c}$ & . & . & . & 33 & . & . & . & . & . \\
\hline Setaria sp. & $\mathrm{c}$ & . & . & . & 3 & . & . & . & . & . \\
\hline Sinapsis arvensis & $\mathrm{s}$ & . & . & . & 3 & . & . & . & . & . \\
\hline Spergula arvensis & $\mathrm{s}$ & . & . & . & 1 & . & . & . & . & . \\
\hline Stellaria media & $\mathrm{s}$ & . & . & . & 1 & . & . & . & . & . \\
\hline Utrica urens & $\mathrm{f}$ & . & . & . & 1 & . & . & . & . & . \\
\hline cf. Valenariella & $\mathrm{s}$ & . & . & . & . & . & 1 & . & . & . \\
\hline
\end{tabular}

to discuss. Supposed animal fodder plants were found at Lipnik site 5 (ribwort plantain (Plantago lanceolata) - 27 specimens, lesser burnet (Pimpinella saxifraga) - 3 specimens, sorrel (Rumex acetosella) - 11 specimens), Słonowice site $\mathrm{G}$ (ribwort plantain -3 specimen, lesser burnet -1 specimen, sorrel -5 specimens) and Pielgrzymowice site 9 (ribwort plantain - single specimen, sorrel -6 specimens) (Table 4). The presence of these plants in fodder may increase its nutritional parameters (Paszkowski et al., 2016). Common dandelion (Taraxacum officinale) is another species that could increase the taste of fodder. It is scarce at Trzciniec culture sites. Only a single fruit was recorded at site $\mathrm{G}$ in Słonowice. It is also classified as a medicinal and honey plant. It contains essential oils, vitamins, flavonoids and mineral salts and could be desirable in the human diet (Wiąckowski, 2005). Remains of other medicinal plants, like St. John's wort (Hypericum perforatum), the lesser burnet (Pimpinella saxifraga), common dandelion (Taraxacum officinale), oregano (Origanum vulgare), field mint (Mentha arvensis) and ribwort plantain (Plantago laceolata) were all found in pit 302 at Lipnik 5 site. St. John's
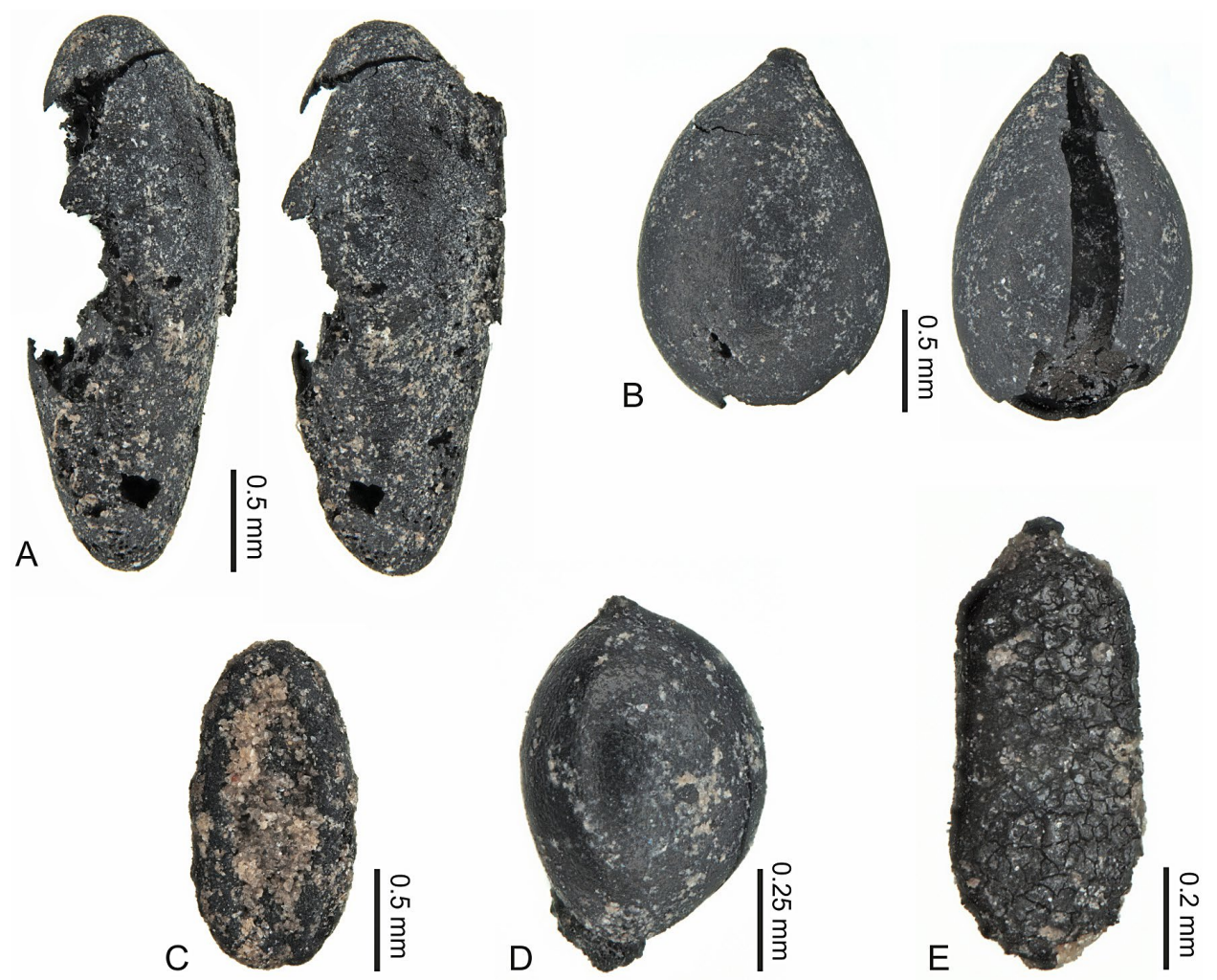

Fig. 3. The Middle Bronze Age, charred plant macro-remains from Pielgrzymowice site 9 , growing in grassland/meadow/pasture. A. Coronilla varia; B. Viola sp.; C. Plantago lanceolata; D. Rumex acetosella; E. Hypericum perforatum 
Table 4. Remains of meadow/pasture from Trzciniec culture sites (southern Poland): ch - charred remains, c - caryopsis, grain, $\mathrm{s}$ - seed, $\mathrm{f}$ - fruit

\begin{tabular}{|c|c|c|c|c|c|c|c|c|c|c|}
\hline Plant name & 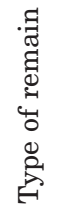 & 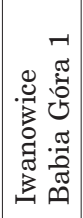 & 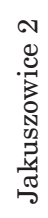 & 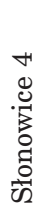 & 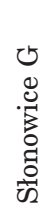 & 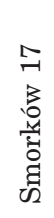 & 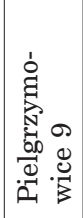 & 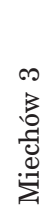 & 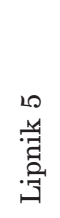 & 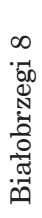 \\
\hline cf. Agrimonia eupatoria & $\mathrm{s}$ & · & $\cdot$ & $\cdot$ & . & $\cdot$ & . & · & 1 & · \\
\hline Arenaria serpyllifolia & $\mathrm{s}$ & . & . & . & 5 & . & $\cdot$ & . & $\cdot$ & . \\
\hline Astragalus cicer / glycyphyllos & $\mathrm{s}$ & . & . & . & $\cdot$ & . & . & . & 9 & . \\
\hline Coronilla varia & $\mathrm{s}$ & $\cdot$ & . & . & $\cdot$ & $\cdot$ & 1 & . & 13 & . \\
\hline Crepis type & $\mathrm{s}$ & . & . & . & . & . & $\cdot$ & . & 4 & . \\
\hline cf. Euphrasia / Odontites & $\mathrm{s}$ & $\cdot$ & · & · & $\cdot$ & $\cdot$ & $\cdot$ & . & 4 & $\cdot$ \\
\hline Hypericum perforatum & $\mathrm{s}$ & . & · & · & · & $\cdot$ & 1 & . & $\cdot$ & . \\
\hline Hypericum tetrapteum / montanum & $\mathrm{s}$ & . & . & . & . & . & . & . & 2 & . \\
\hline Festuca cf. pratensis & $\mathrm{c}$ & $\cdot$ & · & · & $\cdot$ & $\cdot$ & $\cdot$ & . & 6 & $\cdot$ \\
\hline cf. Juncus sp. & $\mathrm{c}$ & . & . & . & . & . & . & . & 4 & . \\
\hline Linum catharticum & $\mathrm{s}$ & $\cdot$ & · & · & $\cdot$ & $\cdot$ & $\cdot$ & · & 2 & $\cdot$ \\
\hline Lithospermum officinale & $\mathrm{f}$ & . & . & . & 1 & . & . & . & $\cdot$ & . \\
\hline Lolium parenne & $\mathrm{c}$ & . & . & . & 1 & . & $\cdot$ & . & . & . \\
\hline Luzula sp. & $\mathrm{c}$ & . & . & . & $\cdot$ & . & . & . & 3 & . \\
\hline Lychnis flos-cuculi & $\mathrm{s}$ & . & . & . & 9 & . & . & . & $\cdot$ & . \\
\hline Medicago lupulina & $\mathrm{f}$ & · & · & · & . & $\cdot$ & . & . & 9 & . \\
\hline cf. Medicago lupulina & $\mathrm{f}$ & . & . & . & $\cdot$ & . & . & . & 14 & . \\
\hline Melandrium album & $\mathrm{s}$ & $\cdot$ & . & . & 14 & . & $\cdot$ & . & $\cdot$ & . \\
\hline Melandrium cf. album & $\mathrm{s}$ & . & . & . & $\cdot$ & . & . & . & 1 & . \\
\hline Mentha arvensis & $\mathrm{f}$ & . & . & . & 1 & . & . & . & $\cdot$ & . \\
\hline Mentha arvensis / M.aquatica & $\mathrm{f}$ & . & . & . & 1 & . & . & . & . & . \\
\hline Nepeta pannonica & $\mathrm{f}$ & . & . & . & 1 & . & . & . & . & . \\
\hline Origanum vulgare & $\mathrm{f}$ & . & . & . & $\cdot$ & $\cdot$ & $\cdot$ & . & 1 & . \\
\hline Phleum pratense & $\mathrm{c}$ & . & . & . & 2 & . & . & . & $\cdot$ & . \\
\hline Phleum / Poa & $\mathrm{c}$ & . & . & . & $\cdot$ & . & . & . & 25 & . \\
\hline cf. Pimpinella saxifraga & $\mathrm{s}$ & . & . & . & $\cdot$ & . & . & . & 3 & . \\
\hline Pimpinella saxifraga & $\mathrm{s}$ & . & . & . & 1 & . & . & . & $\cdot$ & . \\
\hline Plantago lanceolata & $\mathrm{s}$ & · & . & . & 3 & $\cdot$ & 1 & . & 27 & · \\
\hline Plantago media & $\mathrm{s}$ & . & . & . & 1 & . & 1 & . & $\cdot$ & . \\
\hline Plantago media / major & $\mathrm{s}$ & . & . & . & . & . & $\cdot$ & . & 18 & . \\
\hline Poa sp. & $\mathrm{c}$ & . & . & . & 2 & . & 2 & . & $\cdot$ & . \\
\hline Polygonum aviculare & $\mathrm{f}$ & . & . & . & 4 & . & $\cdot$ & . & 8 & $\cdot$ \\
\hline Potentilla reptans & $\mathrm{f}$ & $\cdot$ & $\cdot$ & . & 1 & $\cdot$ & $\cdot$ & . & $\cdot$ & . \\
\hline Prunella vulgaris & $\mathrm{c}$ & . & 1 & . & 2 & . & $\cdot$ & . & 9 & . \\
\hline Rhinantus sp. & $\mathrm{s}$ & . & . & . & $\cdot$ & . & . & . & 4 & . \\
\hline Rumex acetosa & $\mathrm{f}$ & . & . & . & 2 & $\cdot$ & . & . & 3 & · \\
\hline Rumex acetosella & $\mathrm{f}$ & . & . & . & 5 & . & 6 & . & 11 & . \\
\hline Rumex sp. & $\mathrm{f}$ & . & . & $\cdot$ & $\cdot$ & · & $\cdot$ & . & 2 & . \\
\hline Stellaria graminea & $\mathrm{s}$ & . & . & . & 5 & . & 1 & . & 25 & . \\
\hline Taraxacum oficinalle & $\mathrm{f}$ & . & $\cdot$ & . & 1 & . & $\cdot$ & $\cdot$ & $\cdot$ & $\cdot$ \\
\hline Trifolium cf. pratense & $\mathrm{s}$ & . & · & . & $\cdot$ & · & . & . & 1 & . \\
\hline Trifolium sp. & $\mathrm{s}$ & . & . & . & 5 & . & . & . & $\cdot$ & . \\
\hline Verbascum sp. & $\mathrm{s}$ & . & . & . & $\cdot$ & $\cdot$ & . & . & 1 & · \\
\hline Verbena officinalis & $\mathrm{f}$ & . & . & . & $\cdot$ & . & . & . & 1 & . \\
\hline Veronica sp. & $\mathrm{s}$ & . & . & . & 1 & . & . & . & 21 & . \\
\hline Viola sp. & $\mathrm{f}$ & · & $\cdot$ & $\cdot$ & $\cdot$ & $\cdot$ & 1 & · & $\cdot$ & · \\
\hline Trifolieae & $\mathrm{s}$ & . & . & . & 6 & . & . & . & 7 & . \\
\hline
\end{tabular}


Table 5. Remains of various/other plants from Trzciniec culture sites (southern Poland): ch - charred remains, $\mathrm{c}-$ caryopsis, grain, $\mathrm{s}$ - seed, $\mathrm{f}-$ fruit

\begin{tabular}{|c|c|c|c|c|c|c|c|c|c|c|}
\hline Plant name & 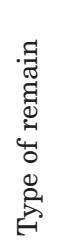 & 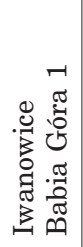 & 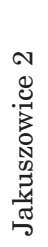 & 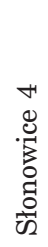 & 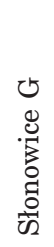 & 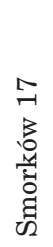 & 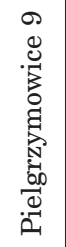 & 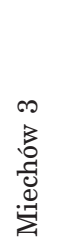 & 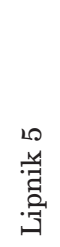 & 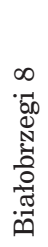 \\
\hline Avena sp. & c & $\cdot$ & $\cdot$ & $\cdot$ & . & · & $\cdot$ & . & 4 & $\cdot$ \\
\hline Astrantia major & $\mathrm{f}$ & . & . & . & . & . & . & . & 4 & . \\
\hline Bromus sp. & c & . & . & $\cdot$ & . & $\cdot$ & $\cdot$ & . & 9 & $\cdot$ \\
\hline Carex sp. & $\mathrm{f}$ & $\cdot$ & $\cdot$ & $\cdot$ & $\cdot$ & $\cdot$ & $\cdot$ & $\cdot$ & 5 & $\cdot$ \\
\hline Crepis type & $f$ & . & . & $\cdot$ & . & $\cdot$ & . & · & 4 & . \\
\hline Cuscuta sp. & $\mathrm{s}$ & · & $\cdot$ & $\cdot$ & $\cdot$ & $\cdot$ & · & $\cdot$ & 1 & $\cdot$ \\
\hline Elatine cf. hexandra & $\mathrm{s}$ & . & $\cdot$ & · & · & · & . & $\cdot$ & 1 & $\cdot$ \\
\hline Fragaria/Potentilla & $\mathrm{f}$ & . & . & . & . & . & . & . & 3 & $\cdot$ \\
\hline Galium palustre & $f$ & . & . & . & 1 & . & . & . & . & $\cdot$ \\
\hline Galium sp. (small) & $f$ & $\cdot$ & . & $\cdot$ & $\cdot$ & . & $\cdot$ & . & 3 & $\cdot$ \\
\hline Quercus sp. (hilum) & $\mathrm{f}$ & $\cdot$ & $\cdot$ & $\cdot$ & $\cdot$ & $\cdot$ & $\cdot$ & $\cdot$ & 29 & $\cdot$ \\
\hline Sambucus sp. & $\mathrm{s}$ & . & · & · & · & · & · & $\cdot$ & 1 & $\cdot$ \\
\hline cf. Geranium & $\mathrm{f}$ & . & · & $\cdot$ & . & · & 1 & $\cdot$ & $\cdot$ & $\cdot$ \\
\hline cf. Glyceria maxima & $f$ & · & · & · & $\cdot$ & · & · & $\cdot$ & $\cdot$ & $\cdot$ \\
\hline Luzula sp. & s & . & . & . & . & . & . & . & 3 & . \\
\hline Malus sylvestris & $\mathrm{f}$ & . & . & . & . & . & . & . & 1 & $\cdot$ \\
\hline Myosotis sp. & $\mathrm{f}$ & . & . & . & . & . & . & . & 1 & $\cdot$ \\
\hline cf. Myosoton aquaticum & s & $\cdot$ & . & $\cdot$ & . & . & $\cdot$ & . & 2 & $\cdot$ \\
\hline Poaceae large & c & . & . & $\cdot$ & . & · & $\cdot$ & . & 8 & $\cdot$ \\
\hline Poaceae small & c & $\cdot$ & · & $\cdot$ & $\cdot$ & · & 14 & $\cdot$ & 547 & $\cdot$ \\
\hline Poaceae indet. & c & $\cdot$ & · & · & 91 & · & $\cdot$ & 3 & $\cdot$ & $\cdot$ \\
\hline Polygonum minus & $\mathrm{f}$ & . & . & . & 3 & . & . & . & . & . \\
\hline Polygonum mite & $\mathrm{f}$ & . & . & . & 3 & . & . & . & . & . \\
\hline Polygonum sp. & $\mathrm{f}$ & . & . & . & 9 & . & $\cdot$ & . & $\cdot$ & $\cdot$ \\
\hline Ranunculus sp. & $\mathrm{f}$ & . & . & . & $\cdot$ & $\cdot$ & $\cdot$ & . & 3 & $\cdot$ \\
\hline Rumex sp. & $\mathrm{f}$ & . & . & $\cdot$ & $\cdot$ & $\cdot$ & $\cdot$ & . & 2 & $\cdot$ \\
\hline Stellaria cf. ulginosa & s & . & · & · & · & · & $\cdot$ & . & 6 & $\cdot$ \\
\hline Stellaria sp./Myosoton aquaticum & $\mathrm{s}$ & · & · & $\cdot$ & $\cdot$ & · & $\cdot$ & $\cdot$ & 8 & $\cdot$ \\
\hline Stachys sp. & $\mathrm{f}$ & . & . & . & 1 & . & . & . & . & . \\
\hline Veronica sp. & $\mathrm{s}$ & . & . & $\cdot$ & $\cdot$ & $\cdot$ & . & . & 21 & $\cdot$ \\
\hline Alliaceae/Liliacea & $\mathrm{s}$ & . & $\cdot$ & . & $\cdot$ & $\cdot$ & $\cdot$ & . & 1 & $\cdot$ \\
\hline Apiaceae indet. & $f$ & $\cdot$ & $\cdot$ & $\cdot$ & $\cdot$ & $\cdot$ & $\cdot$ & . & 4 & $\cdot$ \\
\hline Asteraceae indet. & $\mathrm{f}$ & $\cdot$ & $\cdot$ & $\cdot$ & $\cdot$ & . & . & · & 4 & $\cdot$ \\
\hline Caryophylaceae indet. & $\mathrm{s}$ & $\cdot$ & $\cdot$ & $\cdot$ & · & $\cdot$ & $\cdot$ & $\cdot$ & 47 & $\cdot$ \\
\hline Fabaceae indet. & $\mathrm{s}$ & . & · & · & . & . & . & $\cdot$ & 22 & $\cdot$ \\
\hline Lamiaceae cf. Mentha & $\mathrm{f}$ & . & . & . & . & . & . & . & 1 & . \\
\hline Lamiaceae indet. & $\mathrm{f}$ & . & . & $\cdot$ & . & . & $\cdot$ & $\cdot$ & 5 & $\cdot$ \\
\hline cf. Lamiaceae & $\mathrm{f}$ & . & . & . & . & . & 2 & . & . & . \\
\hline Buds & & . & $\cdot$ & $\cdot$ & . & . & 1 & . & $\cdot$ & $\cdot$ \\
\hline Indetermination & $\mathrm{s} / \mathrm{f}$ & . & $\cdot$ & $\cdot$ & . & $\cdot$ & 166 & . & . & $\cdot$ \\
\hline Cenococcum & & $\cdot$ & . & . & . & $\cdot$ & 27 & $\cdot$ & $\cdot$ & . \\
\hline
\end{tabular}

wort, lesser burnet, plantain, mint, and dandelions are all currently used for medicinal purposes (Polakowska, 1982; Zemanek, 2012; Nawara, 2012; Lewkowicz-Mosiej, 2003). An interesting species is common gromwell (Lithospermum officinale). One fruit has been identified in pit 14 from excavation unit XVI at site G in Słonowice (Lityńska-Zając and Makowicz-Poliszot, 2019).
In the contemporary flora of Poland, this rare species is present predominantly in the lowlands and lower mountain ranges (Baczyńska and Lityńska-Zając, 2005). In addition to medicinal (Baczyńska and Lityńska-Zając, 2005) and ornamental (Jiang et al., 2007) properties, it could also be used as a dye (Mueller-Bieniek and Woch, 2012; Nawara, 2012; Lityńska-Zając 
and Makowicz-Poliszot, 2019) for burial purposes (Baczyńska and Lityńska-Zając, 2005; Kruk et al., 2016). The species has been known since the Neolithic period. It was present at Lendziel and Funnel Beaker culture sites. The medicinal use of this species is suggested based on a find of healing plaster from a grave of the early Bronze Age Mierzanowice culture at Szarbia site 14 (Baczyńska and LityńskaZając, 2005). Several dozen specimens of this species, from Mierzanowicka culture, were also recorded at the Iwanowice-Babia Góra site. Unfortunately, no finds were recorded from the Trzciniec culture features of this site (Kadrow and Lityńska-Zając, 1994). Common gromwell was also present at the Iron Age sites (Sobiejuchy, Jakuszowice, Polanowice and Zofipole), but it was most frequently discovered at early Middle Ages sites (Kaczyce, Kraków Rynek Główny, Kraków Wawel, Kruszwica and Wolin) (Lityńska-Zając, 2005).

Various and unspecified plants were represented at Pielgrzymowice site 9 by 14 grass (Poaceae) caryopses, single geranium (cf. Geranium sp.) seed, and single Labiatae family (cf. Lamiaceae) seed. It is the least numerous group of plants from Trzciniec culture and the species included in it have been identified only at three other sites - Lipnik site 5, Słonowice site G, and Miechów site 3 (Tab. 5). Some species from that group could thrive in various habitats. For example, march-bedstraw (Galium palustre) found at Słonowice site G may inhabit ruderal and forest areas (Zając and Zajac, 2015). Similarly, six-stamen waterwort (Elatine cf. hexandra), water chickweed (Myosoton aquaticum), bog stitchwort (Stellaria cf. ulginosa), or reed mannagrass (cf. Glyceria maxima) found at the Lipnik 5 site are water or/and wetland plants (Kapcia and Mueller-Bieniek, 2019). At Słonowice site G remains of a small group of aquatic plants such as pigmy knotweed (Polygonum minus), knotgrass (Polygonum mite) and marsh-bedstraw (Galium palustre) were confirmed (LityńskaZając and Makowicz-Poliszot, 2019). The small group of forest specimens from Lipnik site 5 includes great masterwort (Astrantia major), wild apple seed (Malus sylvestris), elderberry (Sambucus sp.) and oak acorns (Quercus sp.) (Kapcia and Mueller-Bieniek, 2019). The great masterwort is a very rare specimen in archaeobotanical materials. It is a decorative plant found in deciduous forests and thickets, mainly in southern Poland (Szafer et al., 1969). It can also be found in marshy meadows (Matuszkiewicz, 2001). It could have been brought to pit 302 at Lipnik site 5 accidentally or as an ornamental plant. Most of the plants from this group were not identified to species level. They could have accidentally been brought into the Trzciniec culture settlements, and their presence may indicate that they grew in the area, not necessarily close to the settlement itself.

No data concerning animal bones is available for Pielgrzymowice site 9, preventing a broader analysis of the economy. Similarly, at the Lipnik 5 site, due to the type of soil, no animal bones have been preserved, therefore animal husbandry and the presence of animals can only be concluded indirectly, based on analogies from other sites (Słonowice site G), and ethnographic data. Indirectly, the breeding can be inferred from the presence of meadow plants, tree buds, and small twigs found in pit 302. They may indicate the collection of hay and leaves that may have been used as litter or winter fodder for animals (Wasylikowa, 1999; Lityńska-Zając and Wasylikowa, 2005) or as an insulating layer (Kapcia and Mueller-Bieniek, 2017). At Słonowice site G, animal husbandry is confirmed by the discovery of animal bones, while the use of pastures and meadows in the vicinity of this site can be inferred from the presence of plant remains, e.g. thyme-leaf sandstone (Arenaria serpyllifolia), ragged-robin (Lychnis floscuculi) or lesser stichwort (Stellaria graminea) (Lityńska-Zając and Makowicz-Poliszot, 2019). However, the lack of meadow plants at other Trzciniec culture sites (except for Pielgrzymowice, Słonowice and Jakuszowice) could be the result of the insufficient state of research.

\section{SUMMARY}

The plant assemblage found at Pielgrzymowice site 9 confirmed the use of various cereal species at the settlement of the Trzciniec culture. The most significant finding is the presence of Panicum miliaceum, which belongs to the oldest finds of this cereal in Poland. It is likely that the cultivation of plants was supplemented by food gathering, which may be suggested based on the occurrence of wild plants with edible fruits and seeds such as Chenopodium t. album, Fallopia convulvulus, and Polygonum lapathifolium. In addition, such 
an interpretation of wild herbaceous plant remains can be suggested on the basis of two plant deposits from Lipnik site 5 and Słonowice site $\mathrm{G}$ of the Trzciniec culture, where plants possibly harvested for medicinal, dyeing, or religious purposes were documented and discussed. Also, some plants could have been used as fodder, animal bedding, or for wall insulation. However, some plant remains could have been deposited in archaeological features accidentally. Due to a relatively low number of the archaeobotanical assemblages and a large discrepancy in the botanical material found at the Trzciniec sites mentioned in the paper, it is not possible to reconstruct the plant economy of the Trzciniec culture to a detailed level. Generally, it can be concluded that the diet of the people of the Trzciniec culture was based on cultivated plants and wild plants gathered near the settlements, and to a greater or lesser extent on animal husbandry. Finally, it should be added that an application of a correct archaeobotanical sampling strategy on Trzciniec culture sites is needed to obtain new data and shed more light on the plant-based economy of the Middle Bronze Age populations in Lesser Poland.

\section{ACKNOWLEDGEMENTS}

I thank Dr. hab. Aldona Mueller-Bieniek, my PhD thesis supervisor for her professional guidance and valuable support and Dr. Magdalena Moskal-del Hoyo for her advice and assistance. I would also like to extend my thanks to Krzysztof Stachowicz for photographing plant remains and Agnieszka Sojka for editorial support.

\section{REFERENCES}

Baczyńska, B., Lityńska-Zając, M., 2005. Application of Lithospermum officinale L. in early Bronze Age medicine. Vegetation History and Archaeobotany 14, 77-80. https://doi.org/10.1007/s00334-004-0054-7

Behre, K. E., 2008. Collected seeds and fruit from herbs as prehistoric food. Vegetation History and Archaeobotany 17, 65-73. https://doi.org/10.1007/ s00334-007-0106-x

Bieniek, A., 2007. Neolithic plant husbandry in the Kujawy region of central Poland. In: Colledge, S., Conolly, J. (eds), The Origins and Spread of Domestic Plants in Southwest Asia and Europe. University College London Institute of Archaeology Publications, London, pp. 327-342.

Bieniek, A., 2008. Pozostałości paszy zwierzęcej? Archeobotaniczne badania jamy 302 ze stanowiska 5 w Lipniku pow. Przeworsk. In: Przybyła, M., Blajer, W. (eds) Struktury osadnicze w epoce brąu i wczesnej epoce żelaza na obszarze podkarpackiej wysoczyzny lessowej między Wisłokiem a Sanem. Wydawnictwo Uniwersytetu Jagiellońskiego, Kraków, pp. 319-325.

Calderoni, G., Gancarski, J., Lityńska-Zając, M., Tunia, K., 1998-2000. Radiocarbon dating and Palaeobotanical data from the Bronze Age assemblages of Słonowice and Trzcinica sites (Kielce and Krosno provinces, southern Poland). Origini 22, 267-298.

Dąbrowski, J., 2004. Ältere Bronzezeit in Polen. Starsza epoka brązu w Polsce. Warszawa. Instytut Archeologii i Etnologii, Polskiej Akademii Nauk.

Filipović, D., Meadows, J., Dal Corso, M., Kirleis, W., Alsleben, A., Akeret, Ö., Bittmann, F., Bosi, G., Ciută, B., Dreslerová, D., Effenberger, H., Gyulai, F.G., Heiss, A.G., Hellmund, M., Jahns, S., Jakobitsch, T., Kapcia, M., Klooß, S., Kohler-Schneider, M., Kroll, H., Makarowicz, P., Marinova, E., Märkle, T., Medović, A., Mercuri, A.M., Mueller-Bieniek, A., Nisbett, R., Pashkevich, G., Perego, R., Pokorný, P., Pospieszny, Ł., Przybyła, M., Reed, K., Rennwan, J., Stika, H., Stobbe, A., Tolar, T., Wasylikowa, K., Wiethold, J., Zerl, T., 2020. New AMS ${ }^{14} \mathrm{C}$ dates track the arrival and spread of broomcorn millet cultivation and agricultural change in prehistoric Europe. Scientific Reports 10, 13698. https://doi. org/10.1038/s41598-020-70495-z

Górski, J., 2017. The Trzciniec culture. On the periphery of Bronze Age civilization (1800-1100 BC). In: Bugaj, U. (ed.), The Past Societies. Polish lands from the first evidence of human presence to the Early Middle Ages 3: 2000-500 BC. Institute of Archaeology and Ethnology, Polish Academy of Sciences. Warszawa. pp. 87-126.

Górski, J., Makarowicz, P., Taras, H., 2004. Podstawy gospodarcze ludności kręgu trzcinieckiego w dorzeczach Wisły i Odry. In: Kośko, A., Szmyt, M. (eds), Nomadyzm a pastoralizm w międzyrzeczu Wisły i Dniepru (neolit, eneolit, epoka brązu). Wydawnictwo Poznańskie, Poznań, pp. 191-213.

Hidalgo, A., Brandolini, A., 2014. Nutritional properties of einkorn wheat (Triticum monococcum L.). Journal of the Science of Food and Agriculture 94, 601-612. https://doi.org/10.1002/jsfa.6382

Jankowska, M., Kędzior, Z., Pruska-Kędzior, A., Chojnacka, E., Binder, M., 2011. Porównania właściwości funkcjonalnych glutenu pszenicy samopszy i pszenicy zwyczajnej. Żywność. Nauka. Technologia. Jakość. 6(79), 79-90.

Jiang H.-E., Li X., Liu Ch.-Ji., Wang Y.-F., Li Ch.- S., 2007. Fruits of Lithospermum officinale L. (Boraginaceae) used as an early plant decoration (2500 years BP) in Xinjiang, China. Journal of Archaeological Science 34(2), 167-170. https://doi. org/10.1016/j.jas.2006.04.003

Kaczanowski, P., Kozłowski, J.K., 1998. Najdawniejsze dzieje ziem polskich (do VII w.). Vol 1. Kraków. Oficyna Wydawnicza Fogra. 
Kadrow, S., Lityńska-Zając, M., 1994. Analiza materiałów roślinnych ze stanowisk wczesnej epoki brązu w Iwanowicach. Polish Botanical Studies, Guidebook Series 11, 31-35.

Kapcia M., Mueller-Bieniek A., 2017. Żołędzie (Quercus sp.) jako źródło pożywienia i paszy w pradziejowej gospodarce. Fragmenta Floristica et Geobotanica Polonica 24(1), 133-155.

Kapcia, M., Mueller-Bieniek, A., 2019. An insight into Bronze Age subsistence strategy in forested Carpathian foothills, based on plant macro-remains. Archaeological and Anthropological Sciences 11, 2879-2895. https://doi.org/10.1007/s12520-018-0720-9

Kruk, J., Lityńska-Zając, M., Milisauskas, S., 2016. Gospodarka roślinna w neolicie. Studium przypadku - Bronocice. Kraków. Instytut Archeologii i Etnologii Polskiej Akademii Nauk.

Kulpa, Wł., 1974. Nasionoznastwo chwastów. Warszawa. Państwowe Wydawnictwo Rolnicze i Leśne. 2nd ed.

Lewkowicz-Mosiej, T., 2003. Leksykon roślin leczniczych. Warszawa. Świat Książki.

Libera, J., 2001. Krzemienne formy bifacjalne na terenach Polski i zachodniej Ukrainy (od środkowego neolitu do wczesnej epoki żelaza). Lublin. Uniwersytet Marii Curie-Skłodowskiej.

Libera, J., 2014. Zabytki kamienne z otuliny Poleskiego Parku Narodowego (przyczynek do badań prahistorii centralnej części Polesia Podlaskiego: Wiązowiec). Studia i materiały do badań nad neolitem i wczesną epoką brązu na Mazowszu i Podlasiu vol. IV, 5-30.

Lityńska-Zając, M., 1994. Szczątki roślinne ze stanowisk Babia Góra I, II, III i z Góry Wysyłek w Iwanowicach, woj. Kraków. Sprawozdania Archeologiczne 46, 135-146,

Lityńska-Zając, M., 1997. Roślinność i gospodarka rolna w okresie rzymskim. Studium Archeobotaniczne. Kraków. Instytut Archeologii i Etnologii Polskiej Akademii Nauk.

Lityńska-Zając, M., 1999. Badania archeobotaniczne na stanowisku 2 w Jakuszowicach, gm. Kazimierza Wielka, woj. Świętokrzyskie. In: Wasylikowa, K. (ed.), Rośliny w dawnej gospodarce człowieka. Polish Botanical Studies. Guidebook Series 23, pp. 183-195.

Lityńska-Zając, M., 2005. Chwasty w uprawach roślinnych w pradziejach i wczesnym średniowieczu. Kraków. Instytut Archeologii i Etnologii Polskiej Akademii Nauk.

Lityńska-Zając, M., 2007. Early Neolithic agriculture in south Poland reconstructed from archaeobotanical plant remains. In: Colledge, S., Conolly, J. (eds), The Origins and Spread of Domestic Plants in Southwest Asia and Europe. University College London Institute of Archaeology Publications. London, pp. 315-326.

Lityńska-Zając, M., 2010. Botanical analysis of the multicultural site in Smroków, Słomniki commune. Sprawozdania Archeologiczne 62, 335-352.

Lityńska-Zając, M., Makowicz-Poliszot, D., 2019. Gospodarka rolno-hodowlana ludności kultury trzcinieckiej na popdstawie źródeł przyrodniczych ze stanowiska G w Słonowicach gm. Kazimierza Wielka. Kraków. Instytut Archeologii i Etnologii Polskiej Akademi Nauk.

Lityńska-Zając, M., Wasylikowa, K., 2005. Przewodnik do badań archeobotanicznych. Vademecum Geobotanicum. In: Faliński, J.B. (ed. of series). Sorus. Poznań.

Lityńska-Zając, M., Wasylikowa, K., Cywa, K., Madeyska, E., Tomczyńska, Z., 2014. Badania archeobotaniczne na stanowiskach 10, 11 i $12 \mathrm{w}$ Targowisku, gm. Kłaj, woj. małopolskie. In: Górski, J. (ed.), Kompleks osadniczy kultury łużyckiej w Targowisku, stan. 10-12, pow. wielicki. Via Archaeologica. Źródła z badań wykopaliskowych na trasie autostrady A4 w Małopolsce. Kraków: Krakowski Zespół do Badań Autostrad, Kraków, pp. 243-275.

Lityńska-Zając, M., Cywa, K., Tomczyńska, Z., Wasylikowa, K., Madeyska, E., Koziarska, A., Skawińska-Wieser, K., 2015. Badania archeobotaniczne na wielokulturowym stanowisku 2 w Zagórzu, gm. Niepołomice, woj. małopolskie. Raport 10, 161-186.

Lityńska-Zając, M., Czekaj-Zastawny, A., Rauba-Bukowska, A., 2017. Utilisation of Cultivated and Wild Plants in the Economy of the Linear Pottery Culture in the Upper Vistula Basin. Sprawozdania Archeologiczne 69, 271-296.

Machnik, J., 1998. Kryteria identyfikacji „Trzcińca”. Uwagi wprowadzające. In: Kośko, A., Czebreszuk, J. (eds), Trzciniec. System kulturowy czy interkulturowy proces? Wydawnictwo Poznańskie, Poznań, pp. 13-15.

Makarowicz, P., 1998. Kujawski nurt trzcinieckiego kręgu kulturowego - podstawy taksonomiczne. In: Kośko, A., Czebreszuk J. (eds), Trzciniec. System kulturowy czy interkulturowy proces? Wydawnictwo Poznańskie, Poznań, pp. 33-60.

Makarowicz P., 2010. Trzciniecki krąg kulturowywspólnota pogranicza Wschodu i Zachodu Europy. T. 3. Poznań.

Matuszkiewicz, W., 2001. Przewodnik do oznaczania zbiorowisk roślinnych Polski. Warszawa. PWN.

Moskal-del Hoyo, M., 2021. Open canopy forests of the loess regions of southern Poland: A review basedon wood charcoal assemblages from Neolithic and Bronze Agearchaeological sites. Quaternary International 593-594, 204-223. https://doi. org/10.1016/j.quaint.2020.11.013

Moskal-del Hoyo, M., Lityńska-Zając, M., Korczyńska, M., Cywa, K., Kienlin, T.L., Cappenberg, K., 2015. Plants and environment: results of archaeobotanical research of the Bronze Age settlements in the Carpathian Foothills in Poland. Journal of Archaeological Science 53, 426-444. https://doi. org/10.1016/j.jas.2014.10.024

Motuzaite-Matuzeviciute, G., Staff, R.A., Hunt, H.V., 2013. The early chronology of broomcorn millet (Panicum miliaceum) in Europe. Antiquity 87, 10731085. https://doi.org/10.1017/S0003598X00049875 
Mueller-Bieniek, A., Woch, M.W., 2012. Właściwości użytkowe i ekologiczne oraz kody roślin znalezionych w warstwach archeologicznych sredniowiecznego Krakowa. In: Mueller Bieniek, A. (ed.), Rośliny w życiu codziennym średniowiecznego Krakowa. Instytut Botaniki im. W. Szafera, Polska Akademia Nauk, Kraków, pp. 167-184.

Mueller-Bieniek, A., Kittel, P., Muzolf, B., Muzolf, P., 2015. Useful plant from the site Lutomiersk Kozłówki near Łódź (central Poland) with special reference to the earliest find of Xanthium strumarium L. seeds in Europe. Journal of Archaeological Science: Reports 3, 275-284. https://doi. org/10.1016/j.jasrep.2015.06.025

Mueller-Bieniek, A., Moskal-del Hoyo, M., Kapcia, M., Przybyła, M.M., 2018. Traces of supposed Neolithic plant husbandry in the multicultural site 3 at Miechów, southern Poland. In: Valde-Nowak, P., Sobczyk, K., Nowak, M., Źrałka, J. (eds), Amici magistro et collegae suo Ioanni Christopho Kozłowski dedicant. Wydawnictwo Alter, Uniwersytet Jagielloński, Kraków, pp. 601-608.

Mueller-Bieniek, A., Pyzel, J., Kapcia, M., 2020. Chenopodium seeds in open-air archaeological sites How to not throw the baby out with the bathwater. Environmental Archaeology 25, 69-81. https://doi. org/10.1080/14614103.2018.1536500

Nawara, Z., 2012. Rośliny łąkowe. Warszawa. Multico.

Nowak, M., Lityńska-Zając, M., Moskal-del Hoyo, M., Mueller-Bieniek, A., Kapcia, M., Kotynia, K., 2020. Plants of the Funnel Beaker culture in Poland. Sprawozdania Archeologiczne 72(1), 87-114.

Paszkowski, A., Golińska, B., Goliński, P., 2016. Zioła łąkowe jako składnik mieszanek na użytki zielone w świetle badawczym i aplikacyjnym. Grassland Science in Poland 19, 219-228.

Peng, J., Sun, D., Nevo, E., 2011. Wild emmer wheat, 'Triticum dicoccoides', occupies a pivotal position in wheat domestication process. Australian Journal of Crop Science 5(9), 1127-1143.

Polakowska, M., 1982. Leśne rośliny zielarskie. Warszawa. Państwowe Wydawnictwo Rolnicze i Leśne. 2nd ed.
Rutkowski, L., 1998. Klucz do oznaczania roślin naczyniowych Polski Niżowej. Warszawa. Wydawnictwo naukowe PWN.

Strzelczyk, J.E., 2003. Proso zwyczajne (Panicum miliaceum L.) we wczesnym średniowieczu Wielkopolski. Poznań. Bogucki Wydawnictwo Naukowe.

Szafer, W., Kulczyński, S., Pawłowski, B., 1969. Rośliny polskie. Warszawa. PWN.

Urban, J., 2008. Uprawa roli w kulturze trzcinieckiej - zarys problematyki. In: Mogielnicka-Urban, M. (ed.), Opera ex aere. Studia z epoki brązu i wczesnej epoki żelaza dedykowane prof. J. Dąbrowskiemu przez przyjaciół, uczniów i kolegów z okazji 70-lecia urodzin. Instytut Archeologii i Etnologii PAN, Warszawa, pp. 101-109.

Wasylikowa, K., 1999. Pożywienie zwierząt domowych w czasach prehistorycznych w świetle znalezisk archeobotanicznych. In: Wasylikowa, K. (ed.), 1999, Rośliny w dawnej gospodarce człowieka. Warsztaty archeobotaniczne. Polish Botanical Studies Guidebook Series 23. Instytut Botaniki im. W. Szafera Polskiej Akademii Nauk, Kraków, pp. 343-365.

Wiąckowski, S.K., 2005. Żywienie, żywność, składniki pokarmowe a zdrowie. Kielce. Stanisław K. Wiąckowski.

Zając, M., Zając, A., 2015. Survival problems of archaeophytes in the polish flora. Biodiversity: Research and Conservation 35, 47-56. https://doi. org/10.2478/biorc-2014-0015

Zemanek, A., 2012. Wybrane rośliny średniowiecznego Krakowa w polskich zielnikach renesansu. In: Mueller-Bieniek, A. (ed.), Rośliny w życiu codziennym średniowiecznego Krakowa. Instytut Botaniki im. W. Szafera, Polska Akademia Nauk, Kraków, pp. 211-242.

Zohary, D., Hopf, M., 2000. Domestication of plants in the Old World: The origin and spread of cultivated plants in West Asia, Europe and the Nile Valley. Oxford. Oxford University Press. 3rd ed. 